〔32〕空気中前照射法によるポリエチレンへの

塩化ビニルグラフト共重合

(1965 年 8 月 11 日受理)

上田二 士*

要 旨 ポリエチレンー塩化ビニルグラフトポリマーの合成を 空気中前照射法によって行ない，前照射 線量, 重合温度などの合成条件と見かけ, および真のグラフト率, グラフト効率, ホモポリマー重合度などの 関倸を求め, グラフト機棤について考察した。その結果は次のようである。1) 真のグラフト率は見かけのグ ラフト率の $40 \sim 100 \%$ であり，重合条件などによって変化する。2）真のグラフト速度のアルレニウスプロッ

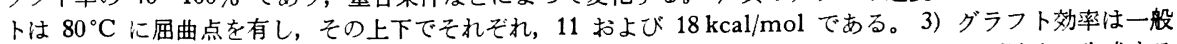
に $30 \%$ 以下であり, 重合温度が高いほどグラフト効率は低、。4) ポリエチレン中, および液中に生成する ホモポリマーの分子量は等しく，それは主として重合温度によって変化する。

\section{1. 緒言}

空気中前照射法によるグラフトポリマーの合成は同時 照射法に比べて放射線の利用効率が低いが，比較的に操 作も簡単で, 電子線の利用により多量のポリマーを処理 できる利点がある。

筆者らはさきに，ポリェチレンに対する塩化ビニルの グラフト重合を同時照射法による気相法で行ない1), 二 三のすぐれた性質をもつポリマーを合成した ${ }^{2)}$ 。本報で は空気中前照射法によるグラフト重合をポリエチレンー 塩化ビニル (液相) 系について行ない, 前照射線量, 重合 温度などの合成条件と, 見かけ, および真のグラフト率, グラフト効率などとの関係を明らかにし，グラフト機構 について考察した。

\section{2. 実験方法}

\section{1 試 料}

ポリエチレンは厚さ $0.02 \mathrm{~mm}$ の高密度ポリェチレン (Hizex), および低密度ポリエチレン(Sumikathene)の 市販のフィルムを主として用いた。試料は $5 \times 5 \mathrm{~cm}$ の 大きさに切断し, 溶剤としてテトラヒドロフランを使用 し, ソックスレー抽出器により 7 時間抽出後, 真空乾燥 した。

\section{2 照射および重合}

抽出試料は乾燥した試験管に入れ, $27^{\circ} \mathrm{C}$ の温度で Co-60により $\gamma$ 線照射を行なった。照射線量率は 6.7 $\times 10^{4} \mathrm{r} / \mathrm{hr}$, 照射線量は $1.27 \mathrm{Mr}, 2.75 \mathrm{Mr}$, および $5.23 \mathrm{Mr}$ である。照射試料は一定時間 (一般に一週間) 室温に放置した後, 直径 $20 \mathrm{~cm}$ の重合管に試料を 2 枚 入れ，ボンベより取り出し，ソーダ石灰およびシリカゲ ルを通して塩化ビニルを真空で導入し, 液体窒素で泠却

* 日本電信電話公社電気通信研究所茨城支所 (茨城県那珂郡東 海村)
捕集した。ついでアルゴンガスで置換し，2 回脱気をく り返した後，真空 $\left(10^{-2} \mathrm{mmHg}\right)$ にして封管した。使用 した塩化ビニルは各重合管に $12 \mathrm{ml}$ である。重合は $55^{\circ} \mathrm{C}$ から $100^{\circ} \mathrm{C}$ の温度で行なった。なお，線量率は Victreen 線量率計で測定した。

\section{3 グラフトポリマーの処理}

重合を終った試料はメタノール中に沈殿し，口過後真 空乾燥して重量を測定した $(A \mathrm{~g})$ 。次にテトラヒドロフ ラン中で 3 昼夜放置し, ホモポリマーを抽出し, 真空乾 燥して見かけのグラフトポリマーとした $\left(W_{1} \mathrm{~g}\right) 。$ 一方, 抽出液中のホモポリマーはメタノールで沈殿し, 回収し た。もとのポリェチレンの重量を $W_{0} \mathrm{~g}$ とすると,

$$
\text { 見かけのグラフト率 }\left(G_{a} \%\right)=\frac{W_{1}-W_{0}}{W_{0}} \times 100
$$

である。

次にこのポリマーをソックスレー抽出器を用い, $65^{\circ} \mathrm{C}$ の温度でテトラヒドロフランにより恒量になるまで抽出 し(48 時間), 真空乾燥して真のグラフトポリマーとし た $\left(W_{2} \mathrm{~g}\right)$ 。真のグラフト率とグラフト効率は (2), (3) 式 で求められるが，グラフト率の決定には元素分析および 赤外吸収スペクトル法を併用した。

$$
\begin{aligned}
\text { 真のグラフト率 }\left(G_{c} \%\right) & =\frac{W_{2}-W_{0}}{W_{0}} \times 100 \\
\text { グラフト効率 }(E \%) & =\frac{W_{2}-W_{0}}{A-W_{0}} \times 100
\end{aligned}
$$

\section{4 顕微鏡写真}

試料をミクロトームで切断し, 干涉法 ${ }^{3)}$ による顕微鏡 写真により, 厚さ方向のグラフトポリマーの濃度分布を 観察した。 


\section{5 ホモポリマーの重合度の測定}

抽出したホモポリマーの重合度を浸透圧法, および粘 度法によって測定した。すなわち, 数平均分子量は Mecrolab の高速度浸透圧測定器によりテトラヒドロフ ランを溶媒として, $25^{\circ} \mathrm{C}$ の温度で測定して求めた。粘 度法ではテトラヒドロフランを溶媒とし, ウベローデ粘 度計により, $25^{\circ} \mathrm{C}$ で測定し, 重量平均分子量 $\bar{M}_{w}$ は次 式より求めた。

$$
[\eta]=1.63 \times 10^{-4} \bar{M}_{w}^{0.766}
$$

\section{3. 実験結果および考察}

\section{1 照射によるポリエチレンの酸化}

Fig. 1 は高密度ポリエチレン, および低密度ポリェ チレンを空気中で $\gamma$ 線照射したときのポリマーの重量 変化を示す。照射線量の增加に従い, 酸化が進行してポ リマーの重量が増大している。このフィルムの赤外吸収 スペクトルの一例を Fig. 12 に示すが, $1720 \mathrm{~cm}^{-1}$ のカ ルポニル基 $\mathrm{C}=\mathrm{O}$ の吸収が見られ, 照射線量の増加とと もに強くなるが，空気中照射の際に認められている5， $3450 \mathrm{~cm}^{-1}$ の水酸基, あるいは八イドロパーオキサイド 基, $870 \mathrm{~cm}^{-1}$ のパーオキサイドの吸収は見られなかっ た。これは試料が薄く，また線量も比較的低いために現

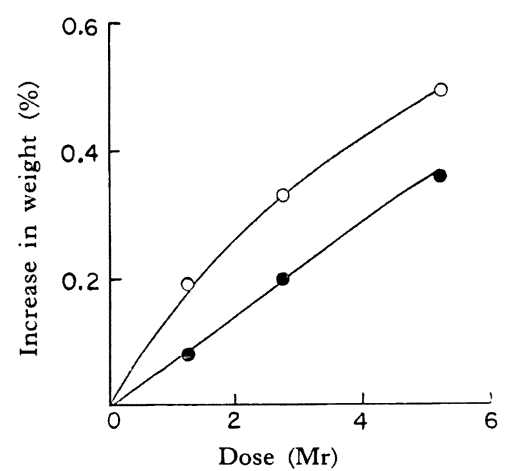

PE

$\mathrm{O}$ : High density,

: Low density

Fig. 1. Increase in weight of irradiated polyethylene as a function of dose.

われなかったのであろらと思われる。実際, $0.2 \mathrm{~mm} の$ 厚さの試料では, ハイドロパーオキサイド基の吸収が見 られた。

3.2 グラフトポリマーの分離

ポリマーの固相中に含有されているホモポリマーは室 温で溶䏒に放置するだけでは, 完全に抽出することは困

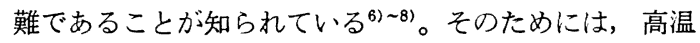

Table 1. Extent of covalent grafting.

\begin{tabular}{|c|c|c|c|c|c|c|}
\hline Polymer & $\begin{array}{c}\text { Preirradiation } \\
\text { dose } \\
\text { (Mr) }\end{array}$ & $\begin{array}{c}\text { Grafting } \\
\text { temperature } \\
\left({ }^{\circ} \mathrm{C}\right)\end{array}$ & $\begin{array}{l}\text { Grafting } \\
\text { time } \\
\text { (hr) }\end{array}$ & $\begin{array}{l}\text { Apparent } \\
\% \text { graft } \\
\left(G_{a}\right)\end{array}$ & $\begin{array}{l}\text { Covalent } \\
\% \text { graft } \\
\quad\left(G_{c}\right)\end{array}$ & $\begin{array}{l}\text { Extent of } \\
\text { covalent grafting } \\
\left(G_{c} / G_{a}\right)\end{array}$ \\
\hline \multirow{11}{*}{$\begin{array}{l}\text { High } \\
\text { density }\end{array}$} & 1.27 & 70 & 8 & 5.3 & 3.6 & 0.69 \\
\hline & 1.27 & 84 & 4 & 4.7 & 3.1 & 0.67 \\
\hline & 1.27 & 84 & 8 & 9.5 & 6.6 & 0.69 \\
\hline & 2.75 & 55 & 24 & 5.2 & 3.4 & 0.65 \\
\hline & 2.75 & 70 & 6 & 4.7 & 3.6 & 0.76 \\
\hline & 2.75 & 84 & 4 & 5.8 & 3.1 & 0.62 \\
\hline & 2.75 & 84 & 6 & 12.6 & 8.1 & 0.64 \\
\hline & 2.75 & 100 & 2 & 8.4 & 5.5 & 0.65 \\
\hline & 2.75 & 100 & 4 & 15.4 & 10.5 & 0.68 \\
\hline & 5.23 & 70 & 4 & 4.6 & 3.2 & 0.69 \\
\hline & 5.23 & 84 & 6 & 17.0 & 12.7 & 0.75 \\
\hline \multirow{8}{*}{$\begin{array}{c}\text { Low } \\
\text { density }\end{array}$} & 1.27 & 55 & 24 & 18.6 & 6.5 & 0.36 \\
\hline & 2.75 & 70 & 6 & 14.0 & 6.6 & 0.47 \\
\hline & 2.75 & 84 & 8 & 23.6 & 23.1 & 0.98 \\
\hline & 2.75 & 100 & 8 & 26.6 & 26.0 & 0.98 \\
\hline & 5.23 & 70 & 4 & 12.7 & 6.5 & 0.51 \\
\hline & 5.23 & 70 & 8 & 22.5 & 11.9 & 0.53 \\
\hline & 5.23 & 100 & 4 & 21.0 & 21.5 & 1.00 \\
\hline & 5.23 & 100 & 8 & 60.7 & 58.1 & 0.96 \\
\hline
\end{tabular}


で抽出するか, 1 度溶解し粉末にした試料について抽出 することが必要である。筆者はッックスレー抽出器で高 温抽出, および 1 度キシレンで溶解し(一部不溶)粉末に した試料について高温で抽出し，よく一致した結果を得 たので, ソックスレー抽出器によって固相中のホモポリ マーの分離を行なった。Table 1 は種々の条件で得られ たグラフトポリマーについての結果である。高温では小 量のポリエチレン, あるいはグラフトポリマーが抽出さ れるため,グラフト率の決定は赤外分析により行なった。 高密度ポリエチレンでは, 照射および重合条件の違いに かかわらず，真のグラフト率は見かけのグラフト率の $70 \%$ 前後である。低密度ポリェチレンでは, 重合温度に よって非常に違った結果を得ている。すなわち, $100^{\circ} \mathrm{C}$ および $85^{\circ} \mathrm{C}$ の重合温度では見かけのグラフト率と真の グラフト率はほとんど一致しているが，それ以外の温度 では, 真のグラフト率は見かけのグラフト率の $50 \%$ 前 後である。これは, $80^{\circ} \mathrm{C}$ 以上でポリエチレンが塩化ビ ニルモノマーにほとんど溶解し, 重合物が粉末または多 孔質な細片であるため, 常温における抽出で木モポリマ 一が容易に抽出されるためであろら。

\section{3 放置時間の影響}

ポリエチレンは空気中で $\gamma$ 線の照射を受けた場合に もパーオキサイドのみならず,遊離基を生成し、これは酸 素との反応によって漸次消失する ${ }^{9)}$ 。Fig. 2 は $2.75 \mathrm{Mr}$

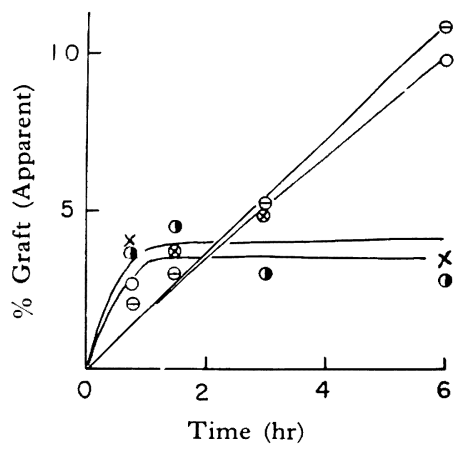

Preirradiation dose $2.75 \mathrm{Mr}$

Grafting temperature $80^{\circ} \mathrm{C}$

Elapsed time after irradiation

C : $0 \mathrm{hr}, \times: 24 \mathrm{hr}, \ominus: 7$ day, $\bigcirc: 23$ day

Fig. 2. Percent graft vs. grafting time for various times of storage.

照射した高密度ポリエチレンを照射直後, および一定時 間空気中で放置した後, 封管し, $80^{\circ} \mathrm{C}$ で重合したとき の見かけのグラフト率の変化を示している。照射直後の ポリエチレンのグラフト重合では，グラフト率はすぐ飽 和するが, 1 週間以上放置した試料は直線的にグラフト 重合が進行し,また， 1 週間と 3 週間の試料の間には重
合経過にはほとんど違いはない。このことは 1 週間以上 放置することによって, 遊䧺基は酸素との反応によって ほとんど消失し, 試料中のパーオキサイドの濃度は一定 になり，重合反応はほとんどパーオキサイドの分解によ って開始することを示すものである。それゆえ，遊離基 の影響を除くため, 以下の実験はすべて照射後 1 週間以 上放置してから重合を行なった。

\section{4 重合温度の影響}

Fig. 3 は見かけおよび真のグラフト重合, Fig. 4 は ホモポリマー生成に及ぼす重合温度の影響の一例を示し たものである。反応の後期で多少, 重合率が飽和する傾 向のものも見られるが，この実験の範囲では一般に原点 を通る直線で表わされる。高密度抢よび低密度ポリエチ

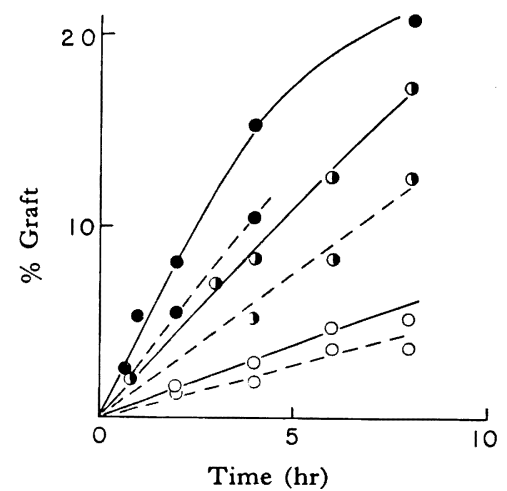

Preirradiation dose $2.75 \mathrm{Mr}$ Grafting temperature $\left({ }^{\circ} \mathrm{C}\right)$ $\bigcirc: 70, \bigcirc: 84, \bigcirc: 100$

Apparent grafting, ---: Covalent grafting

Fig. 3. Percent graft vs. time for various grafting temperatures.

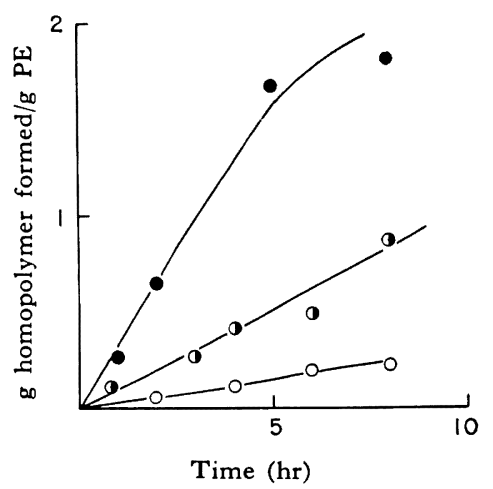

Preirradiation dose $2.75 \mathrm{Mr}$

Grafting temperature $\left({ }^{\circ} \mathrm{C}\right)$ $\mathrm{O}: 70, \bigcirc: 84, \bigcirc: 100$

Fig. 4. Weight of homopolymer formed vs. time for various grafting temperatures. 


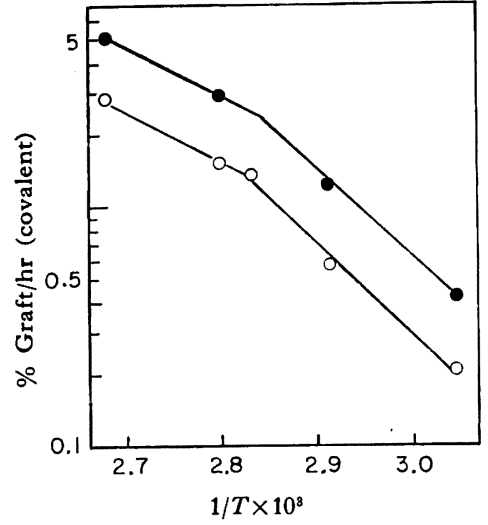

Preirradiation dose $2.75 \mathrm{Mr}$ PE

$\bigcirc$ : High density, : Low density

Fig. 5. Arrhenius plots of the rate of graft polymerization.

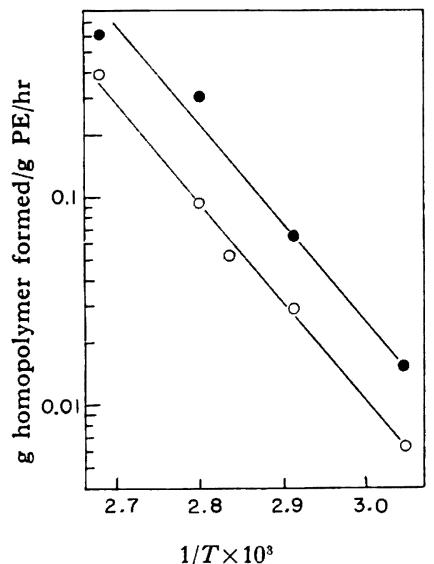

Preirradiation dose $2.75 \mathrm{Mr}$

PE

: High density,

: Low density

Fig. 6. Arrhenius plots of the rate of homopolymer polymerization.

レンの真のグラフト速度, およびホモポリマー生成速度 から求めたアルレニウスプロットを Fig. 5, Fig. 6 に 示した。Fig. 5, 6 から明らかなように，グラフト重合 の場合, 約 $80^{\circ} \mathrm{C}$ に届曲点が存在している。曲線の傾斜 から求めた見かけの活性化エネルギーは高温側, 低温側 でそれぞれ $12 \mathrm{kcal} / \mathrm{mol}$ および $18 \mathrm{kcal} / \mathrm{mol}$ である。省 略したが，照射線量を変えたものについてもほとんど同 様の結果が得られた。グラフト速度のアルレニウスプロ ットに届曲点の存在することは Chapiro がアクリロニ トリルのグラフトの場合に認めており, ポリェチレン結 晶の融解温度約 $100^{\circ} \mathrm{C}$ に相当している ${ }^{10)}$ 。塩化ビニル
Table 2. Swelling of polyethylene in vinyl chloride.

\begin{tabular}{c|c|c}
\hline \multirow{2}{*}{$\begin{array}{c}\text { Temperature } \\
\left({ }^{\circ} \mathrm{C}\right)\end{array}$} & \multicolumn{2}{|c}{ Swelling of polyethylene (\%) } \\
\cline { 2 - 3 } & Low density & High density \\
\hline 25 & 17.3 & 7.3 \\
40 & 23.0 & 8.7 \\
55 & 32.0 & 9.4 \\
70 & 61.8 & 11.5 \\
85 & dissolved & 15.6 \\
100 & - & 21.5 \\
\hline
\end{tabular}

の場合届曲点温度が Table 2 に示すように, 低密度ポ リエチレンのモノマーへの溶解温度, 高密度ポリエチレ ンの膨潤度の増大温度に対応しており, アクリロニトリ ルの場合と同様に低温側では, ポリェチレン結晶領域へ のモノマーの拡散が支配的な因子の一つであると考えら れる。一方, 高温側では Chapiro は粘性の増加による 停止反応の困難性によるものとしているが，後述するよ うにモノマーへの連鎖移動による停止反応の影響が大き いものと考える。

次に, ホモポリマー生成速度のアルレニウスプロット より求めた見かけの活性化ェネルギーは低密度, 高密度 ポリエチレンとも $22 \mathrm{kcal} / \mathrm{mol}$ である。

グラフト効率は重合時間によってほとんど変化しない が, 重合温度によって大きな影響を受ける。Fig. 7 はそ の一例であるが, グラフト率は $30 \%$ 以下であり, 低密 度ポリエチレンの方が高密度ポリエチレンよりいくふんん 小さく, 両者とも重合温度の上昇とともに低下している。 これはオゾン化ポリエチレンへの塩化ビニルのグラフト 重合の結果と一致している ${ }^{11)}$ 。照射線量の異なったもの についてもほぼ同様な結果が得られた。もし，ホモポリ

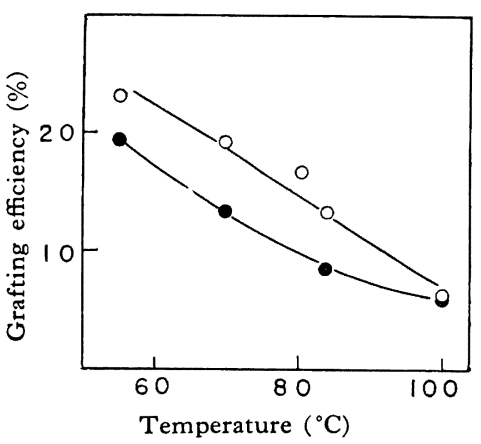

Preirradiation dose $2.75 \mathrm{Mr}$

PE

$\bigcirc$ : High density,

: Low density

Fig. 7. Grafting efficiency vs. grafting temperature for high and low density polyethylene. 
マーの生成がハイドロパーオキサイドの $\mathrm{OH}$ ラジカル, ジパーオキサイドの低分子量分解物質の開始反応にのみ 由来するならば, グラフト効率は重合温度によってむし ろ，上昇するはずであり，実験結果に見られる温度の影 響や，30\% 以下といら低いグラフト効率を 説明するこ とは困難である。一方，塩化ビニルは特に高温で連鎖移 動を受けやすいことが知られており ${ }^{12)}$ ，連鎖移動がホモ ポリマーの生成に大きな役割をもつことが推定される。

\section{5 照射線量の影響}

高密度ポリエチレン, 低密度ポリエチレンについて, 横軸に照射線量, 縦軸に重合速度の各対数をとり, 真の グラフト速度, およびホモポリマー生成速度についてプ ロットしたものの一例を Fig. 8, Fig. 9 に示す。重合

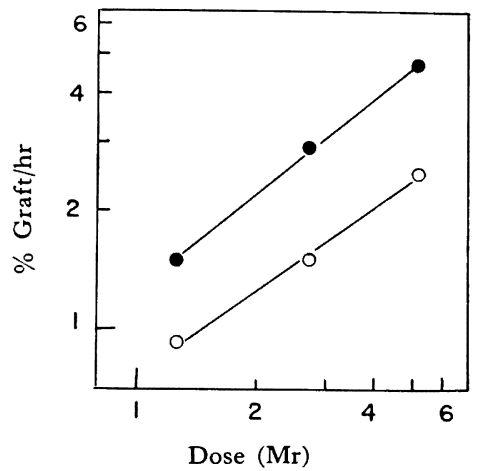

Grafting temperature $84^{\circ} \mathrm{C}$ PE

$\bigcirc$ : High density, $\bigcirc$ : Low density

Fig. 8. Influence of preirradiation dose on the rate of graft copolymerization.

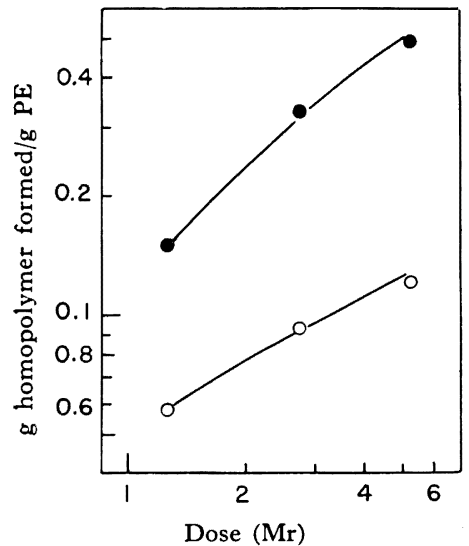

Grafting temperature $84^{\circ} \mathrm{C}$

PE

$\bigcirc$ : High density, : Low density

Fig. 9. Influence of preirradiation dose on the rate of homopolymer polymerization.
速度を $V$, 照射線 量を $D$ とすると $V \propto K D^{\alpha}$ が成立 し，重合温度によって多少の差異はあるが，グラフト重 合の場合, 高密度ポリエチレン, および低密度ポリェチ レンについて平均值として $\alpha$ はそれぞれ 0.57 および 0.74 である。また, ホモポリマーの場合には 0.52 およ び 0.81 である。

低密度ポリエチレンと, 高密度ポリエチレンの指数 $\alpha$ の違いは, 高密度ポリェチレンの場合, 照射後効果で知 られているように ${ }^{18)}$, 酸化速度, あるいはパーオキサイ ドの生成速度が遅く, ポリェチレンのパーオキサイドの 濃度が必ずしも線量に比例しないためと思われる。

\section{6 厚さの影響とグラフト濃度分布}

放射線による不均一グラフト重合の場合には, 試料の 厚さの違いが，厚さ方向のグラフト濃度，あるいはグラ フト重合速度に影響を与えることが知られている1),8)。 Fig. 10 は高密度ポリェチレンについて, 照射線量

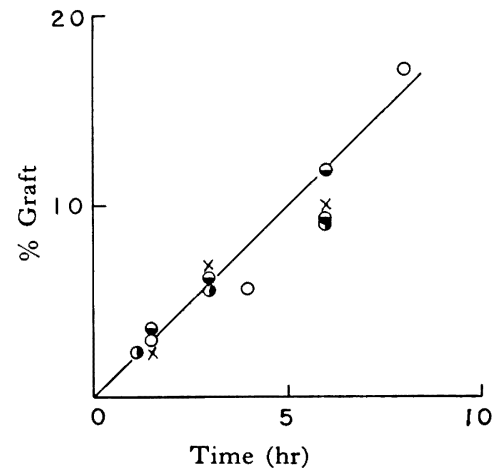

Preirradiation dose $2.75 \mathrm{Mr}$

Grafting temperature $84^{\circ} \mathrm{C}$

Thickness of film (mm)

$\bigcirc: 0.02, \times: 0.1, \bigcirc: 0.2, \ominus: 0.5$

Fig. 10. Percent graft vs. time for various thicknesses of polyethylene.

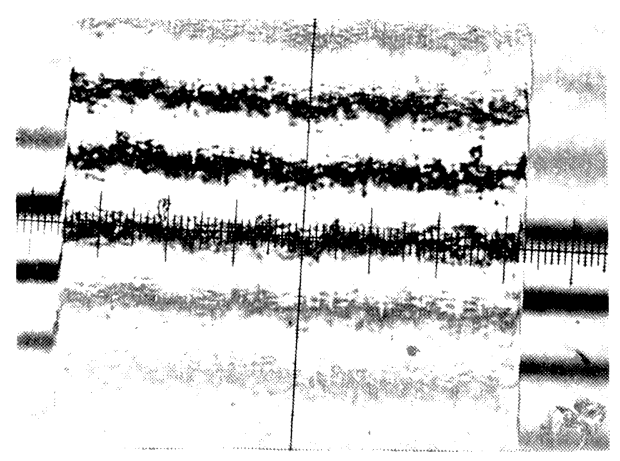

High density PE, thickness $0.5 \mathrm{~mm}, 10 \%$ graft

Fig. 11. Interferometric photographs of graft polymer. 
Table 3. Comparison of molecular weight of polyvinyl chloride in liquid and in film phase.

\begin{tabular}{|c|c|c|c|c|c|c|}
\hline \multirow{2}{*}{ No. } & \multirow{2}{*}{ Polymer } & \multirow{2}{*}{$\begin{array}{l}\text { Preirradiation } \\
\text { dose } \\
(\mathrm{Mr})\end{array}$} & \multirow{2}{*}{$\begin{array}{l}\text { Grafting } \\
\text { temperature } \\
\left({ }^{\circ} \mathrm{C}\right)\end{array}$} & \multicolumn{2}{|c|}{ Molecular weight } & \multirow{2}{*}{$\bar{M}_{w} / \bar{M}_{n}$} \\
\hline & & & & $\bar{M}_{n}$ & $\bar{M}_{w}$ & \\
\hline$A-1^{a)}$ & PVC formed in liquid phase & 2.75 & 75 & 21000 & 39100 & 1.91 \\
\hline$A-2^{a)}$ & PVC homopolymer from the film phase & 2.75 & 75 & 21700 & 33600 & 1.55 \\
\hline$B-1^{b)}$ & PVC formed in liquid phase & 2.75 & 60 & 35700 & 60800 & 1.70 \\
\hline$B-2^{b)}$ & PVC homopolymer from the film phase & 2.75 & 60 & 32400 & 53200 & 1.64 \\
\hline
\end{tabular}

a) Grafting of high density polyethylene

b) Grafting of low density polyethylene

Table 4. Molecuar weight of polyvinyl chloride formed in liquid phase.

\begin{tabular}{c|c|c|c|c}
\hline \hline No. & $\begin{array}{c}\text { Preirradiation dose } \\
(\mathrm{Mr})\end{array}$ & $\begin{array}{c}\text { Grafting temperature } \\
\left({ }^{\circ} \mathrm{C}\right)\end{array}$ & $\begin{array}{c}\text { Grafting time } \\
(\mathrm{hr})\end{array}$ & $\begin{array}{c}\text { Number average } \\
\text { molecular weight }\end{array}$ \\
\hline $3-1-1^{\mathrm{a})}$ & 1.27 & 70 & 2 & 26200 \\
$3-1-3^{\mathrm{a})}$ & 1.27 & 70 & 6 & 35900 \\
$4-2-1^{\mathrm{a})}$ & 2.75 & 84 & 2 & 22400 \\
$4-3-2^{\mathrm{a})}$ & 2.75 & 100 & 4 & 16650 \\
$5-3-2^{\mathrm{a})}$ & 5.23 & 100 & 4 & 16840 \\
$5-3-4^{\text {b) }}$ & 5.23 & 100 & 8 & 19900 \\
\hline
\end{tabular}

a) Grafting of low density polyethylene

b) Grafting of high density polyethylene

$2.75 \mathrm{Mr}$, 重合温度 $85^{\circ} \mathrm{C}$ の重合条件での見かけのグラフ ト率に及ぽす厚さの影響を示している。この条件ではグ ラフト率に関しては厚さの影響はなく, フィルム中に均 一にグラフトしているものと考えられる。このことは干 涉法による顕微鏡写真によって確かめられた (Fig. 11)。 このよらにグラフト率に関して厚さの影響が見られない のは, モノマーの膨潤度が比較的高いこと, 反応が比較 的高温で行なわれるため, ポリェチレンの非晶領域では モノマーが拡散しやすいためであろう。

\section{7 ホモポリマーの重合度}

厚さ $0.1 \mathrm{~mm}$ の低密度および高密度ポリエチレンを グラフト重合後, フィルムをテトラヒドロフランで洗浄 後, 熱キシレンに溶解し(一部不溶), 粉状あるいは細片 にした試料について沸とう，テトラヒドロフランで 7 時 間処理して，ポリマー中に生成したホモポリマーを抽出 し, 抽出液を常温放置後, 口過および遠心分離機により 不溶のポリマーを除き, ポリェチレン中のホモポリマー を分離した。Table 3 は液中, および固相中に生成した ポリマーの分子量の測定結果である。低密度と高密度ポ リエチレンは重合条件が違っているが，いずれも液中と ポリェチレン固相中に生成したホモポリマーの分子量は ほとんど同じである。前照射法によるグラフト重合の場 合, 固相中に生成するホモポリマーと液相中に生成する 水モポリマーの分子量についての測定結果は報告されて
いないが，同時照射法の場合には固相中のホモポリマー の分子量が，液相に生成するホモポリマーより数倍大き いことが報告されている(6) 8)。これはポリマーの固相中 で重合が進行するとき，停止反応がさまたげられ，いわ ゆるゲル効果によって分子量が増大するものとされてい る。ポリ塩化ビニルはモノマーに不溶のため, 塊重合で

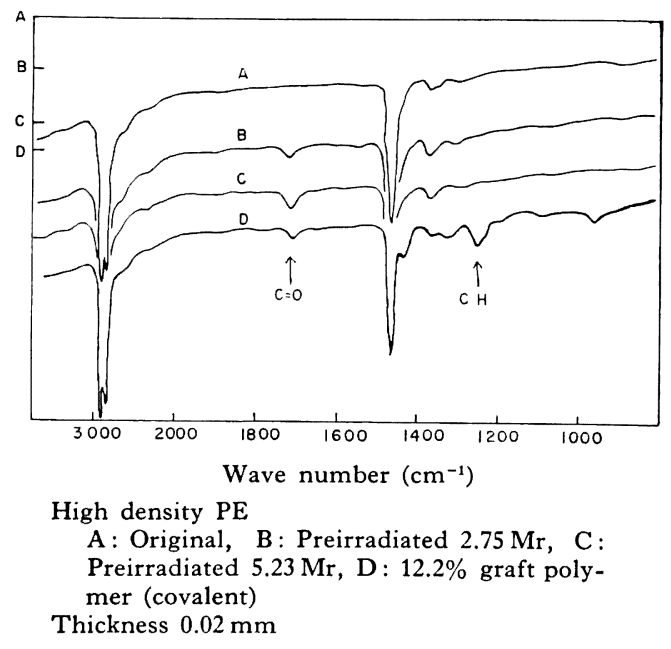

Fig. 12. IR spectrum of polyethylene and graft polymer. 
ゲル効果が認められており, また, 重合の初期, および 90\% 重合率とい5高重合率でも 分子量変化は 比較的小 さく, モノマーへの連鎖移動による停止反応が支配的で あることが知られていることから ${ }^{12) ， ホ ゚ リ ェ チ レ ン 中 の ~}$ ホモポリマーの分子量と液中に生成するホモポリマーの 分子量の等しいことを同様に理解することができる。

Table 4 は $0.02 \mathrm{~mm}$ のポリエチレンについて液相に 生成したホモポリマーの分子量の測定結果であるが，分 子量は重合時間, 前照射線量にあまり関係なく, 重合温 度によって著しい影響を受けている。このことはまた， 塩化ビニルの触媒重合の結果と一致している。

\section{8 グラフトポリマーの赤外吸収スペクトル}

Fig. 12 にポリエチレン, 被照射ポリエチレン,および 真のグラフトポリマーの赤外吸収スペクトルを示す。グ ラフトポリマーは明らかに, ポリ塩化ビニルによる $\mathrm{CH}$ 基の吸収 $1250 \mathrm{~cm}^{-1}$ が強く現われている。また，カル ボニル基の吸収はグラフト重合の前後でほとんど変化せ ず，開始反応に関与しないことは明らかである。

付記：本研究にあたり, 終始ご指導をたまわった松尾博室 長, 干涉法による影微鏡写真の測定に協力された近藤衛氏, 元 素分析をしていただいた園靖之助氏，ならびに実験に協力され た木村健氏, 高田光彦氏に感謝の意を表する。なお, 本研究の 大部分は日本化学会第 18 年会 (昭和 40 年 4 月, 東京) にて発表 した。
文献

1) 門永政雄, 上田二士：高化， 21，657(1964)

2) 上田二士, 門永政雄 : 高化, 23, 165(1966)

3) H. Matsuo, K. Iino, M. Kondo: J. Appl. Polymer Sci., 7, 1833(1963)

4) M. Freeman, P. P. Manning: J. Polymer Sci., A2, 2017 (1964)

5) A. Charlesby: "Atomic Radiation and Polymer", 236(1960), Pergamon Press, London

6) 松田竜夫, 早川 浄, 江田文三, 川瀬 黄 : 高化, 18, 634(1961)

7）住友 宏, 高椋節夫, 八浜義和：工化, 62, 269 (1963)

8) W.K.W. Chen, H. Z. Friedlander: J. Polymer Sci., C4, 1195(1964)

9) Y. Shinohara, K. Tomioka: J. Polymer Sci., 44, 195(1960)

10) A. Chapiro: J. Polymer Sci., 29, 321 (1958)

11）井本 稔, 大津隆行, 山田快蔵：工化, 65, 1875 (1962)

12）近畿化学工業会ビニル部会編集：“ポリ塩化ビニ ル”, 71 (1961) 朝倉書店, 東京

13) A. Chapiro: "Radiation Chemistry of Polymeric System", 430 (1962), Interscience Publishers, New York

\title{
Grafting of Vinyl Chloride onto Polyethylene by the Preirradiation Method
}

\author{
By Kazuo Ueda*
}

Vinyl chloride has been grafted to high and low density polyethylenes by decomposing the peroxides and hydroperoxides, which were previously formed in the polymers by irradiating with $\gamma$-rays in the air. The influence of several parameters such as grafting temperature $\left(55 \sim 100^{\circ} \mathrm{C}\right)$, preirradiation dose $(1.27 \sim 5.23 \mathrm{Mr})$ on the rate of graft polymerization, degree of covalent grafting, grafting efficiency has been studied. The experimental results are discussed and explained on the basis of the chain transfer to monomer and diffusion of monomer to polyethylene. The results are as follows:

a) Degree of covalent grafting lies between 40 to $100 \%$ depending on the grafting condition and kind of polyethylene samples.

b) The Arrhenius plots of the rate of covalent graft copolymerization exhibit a break point at $80^{\circ} \mathrm{C}$, and the overall activation energy are $11 \mathrm{kcal} / \mathrm{mol}$ above and $18 \mathrm{kcal} / \mathrm{mol}$ below the point. Besides the overall activation energy of homopolymerization are $22 \mathrm{kcal} / \mathrm{mol}$.

c) Graft efficiency lies between 5 to $30 \%$ and the efficiency decreases as to the temperature increases.

d) Molecular weight of homopolymers formed in polyethylene has a similar value to that in liquid phase, and depends mainly on the grafting temperature.

e) An uniform distribution of graft concentration across the section is observed.

* Ibaraki Branch, Electrical Communication Iaboratory, Nippon Telegraph and Telephone Public Corporation (Tokai-mura, Ibaraki) 